Michel Christian, Camarades ou apparatchiks? Les communistes en RDA et en Tchécoslovaquie (1945 - 1989), Paris : PUF, 2016, 398 p.

\title{
Valérie LoZAC'H
}

Université de Strasbourg, Laboratoire SAGE (UMR 7363)

Étudier la construction et la stabilisation des régimes communistes à partir de leurs organisations partisanes : c'est le propos de l'ouvrage rédigé par Michel Christian, qui prend appui sur l'examen de deux cas, le SED en RDA et le PCT en Tchécoslovaquie, pour montrer comment ces partis politiques ont œuvré à l'établissement d'un nouvel ordre social en Europe de l'Est.

L'ouvrage suit un découpage chronologique en quatre parties. La première, qui s'étend de 1945 au début des années 1950, retrace l'accession des formations communistes est-allemande et tchécoslovaque au statut de parti d'État. La deuxième partie s'intéresse à la « construction du socialisme », marquée par l'émergence de nouveaux fonctionnements institutionnels et de nouvelles normes de comportement dans les années 1950, tandis que la troisième décrit le processus de routinisation qui accompagne l'arrivée au pouvoir des premières cohortes socialisées sous le régime communiste durant la décennie suivante. La quatrième partie se centre sur les années 1970 et 1980, où le SED et le PCT, qualifiés de " partis de la conservation ", se distinguent par l'extrême régularisation de leurs institutions et de leurs pratiques.

Plusieurs thématiques sont traitées dans cette perspective diachronique et comparative. L'auteur livre tout d'abord une analyse détaillée de la composition sociale des partis communistes. Celle-ci se caractérise par une relative stabilité : les femmes représentent notamment entre 15 et $20 \%$ des membres depuis les années 1950, tandis que les ouvriers forment toujours un tiers des militants dans les années 1980. Cette relative stabilité tient pour large part aux stratégies déployées par les directions partisanes pour favoriser les recrutements féminins et ouvriers. Elle résulte également d'une extension régulière de la catégorie ouvrière destinée à préserver l'identité sociale sur laquelle les partis communistes ont fondé leur légitimité. Ces pratiques ne sauraient toutefois contrecarrer l'augmentation progressive de la part des professions intellectuelles et des employés, qui s'accompagne d'une revalorisation du capital scolaire par rapport au capital politique. Le parti communiste est ainsi passé d'un outil de mobilité sociale, recrutant parmi les travailleurs les moins dotés, à un instrument de reproduction des hiérarchies sociales, où les ouvriers et les femmes restent sous-représentés et occupent des positions dominées face à des cadres de plus en plus diplômés.

Le fonctionnement du parti constitue le deuxième point d'entrée de cette contribution à une sociohistoire du communisme. L'ouvrage met tout particulièrement 
l'accent sur le développement de la bureaucratie partisane, fondée sur l'usage de différents outils - rapports, formulaires d'inscription, fiches d'identification, etc. visant à assurer l'emprise de l'organisation sur ses membres. Engagées dès les années 1950, ces pratiques sont affinées dans la décennie suivante, qui ouvre en même temps une période de réforme en matière de discipline partisane : il s'agit désormais moins de punir que de corriger par le biais de sanctions éducatives. Si les années 1970 et 1980 poursuivent ce perfectionnement de l'emprise bureaucratique, il ne faut pas pour autant cantonner les partis communistes au rôle d'instruments de contrôle. L'étude de la « vie de parti », ponctuée de réunions, de discussions et de formations, montre que ces organisations constituent aussi des cadres de socialisation et des espaces de sociabilité œuvrant à la fabrique des «sujets communistes ». La fréquentation régulière de leurs assemblées contribue en effet à la transmission et l'incorporation de formes légitimes d'exercice du militantisme mobilisant la capacité à prendre la parole et à organiser des débats. Celles-ci participent des processus de sélection et d'ascension sociales qui s'opèrent dans et via les partis communistes en favorisant les membres les mieux dotés en capital scolaire.

L'ouvrage interroge enfin la place du parti dans la société, principalement appréhendée à travers l'ancrage des organisations de base dans les entreprises, les administrations ou encore les coopératives. Il met au jour l'étroite intrication des activités partisanes et professionnelles sous les régimes communistes. Le lieu de travail y forme en effet l'espace politique par excellence, où les activités militantes s'exercent au quotidien. L'auteur déplace ainsi le regard sur les acteurs, les pratiques et les interactions « de terrain », donnant à voir le parti communiste comme un lieu de discussions, de débats et de tensions, à l'instar de celles qui opposent organisations de base et direction des entreprises.

Christian s'appuie sur un minutieux travail d'archives, étayé par de nombreux rapports, directives et statistiques, pour mener une comparaison fine et rigoureuse des partis communistes en RDA et Tchécoslovaquie sur plus de quarante ans. À rebours des lectures statiques et uniformes du bloc soviétique, la double perspective diachronique et comparative permet de saisir l'inscription tant sociale que nationale des partis communistes. En centrant l'attention sur les propriétés sociales et les activités militantes de leurs membres, l'auteur restitue toute la complexité des formations dirigeantes sous le communisme, à la fois structures de pouvoir, où sont recrutées les élites politiques, et organisations de masse, où sont intégrés l'ensemble des groupes sociaux. Il pointe également les évolutions et les contradictions à l'œuvre dans ces partis, passés progressivement du rôle d'agent du changement à celui de garant de l'ordre social. Si la mise en regard des cas tchécoslovaque et est-allemand rappelle l'importance des dynamiques d'homogénéisation qui sous-tendent l'organisation et le fonctionnement des partis communistes sous l'effet d'un alignement sur le modèle soviétique, elle souligne aussi les processus de différenciation qui s'opèrent 
parallèlement sous l'effet de contextes nationaux singuliers. Le SED et le PCT se distinguent en effet sur deux points principaux : le taux d'appartenance et le poids des permanents. Doté d'effectifs exceptionnellement nombreux, le parti tchécoslovaque se caractérise par une forte implantation dans la population sans pour autant disposer d'un appareil puissant. C'est l'inverse pour son homologue est-allemand, qui a davantage contribué à la création d'un « sujet socialiste » en exerçant un contrôle bureaucratique précoce sur ses membres et un encadrement étroit de la « vie de parti ». L'auteur attribue notamment ces différences au rapport particulier que les deux organisations partisanes entretiennent à l'État-nation : le PCT aurait, en quelque sorte, pu faire l'économie d'un appareil puissant en raison de la légitimité qu'il puise dans un discours associant socialisme et nationalisme, contrairement au SED que la concurrence représentée par la RFA aurait privé de cette ressource nationale. L'argumentation, certes pertinente, aurait mérité de plus amples développements pour emporter pleinement l'adhésion. Elle n'explicite pas suffisamment comment s'incarne ce rapport à la nation, dont le contenu reste quelque peu abstrait, ni comment il joue dans la construction de l'identité partisane. Dans le cas du SED, on aurait aimé que soit plus finement analysé l'impact de cette configuration singulière liée à la partition de l'Allemagne sur le fonctionnement du parti. Plus généralement, les contextes nationaux sont parfois trop brièvement évoqués pour restituer concrètement la manière dont s'y inscrivent les deux partis. Prenons à nouveau l'exemple de la RDA, où plusieurs organisations, qualifiées de partis du Bloc, formaient un Front national placé sous l'autorité du SED. Il aurait été intéressant de prendre en considération leur existence pour comprendre les ressorts de l'engagement au sein du parti dirigeant. Pourquoi choisit-on d'adhérer au SED plutôt que de rejoindre les formations démocrates-chrétiennes ou libérales estallemandes : est-ce un effet de la socialisation familiale ou parce que les perspectives de rétribution sociale et professionnelle y sont bien plus attrayantes?

Ces interrogations nous amènent à soulever une autre série de réflexions, qui ont trait à l'étude des trajectoires militantes. L'auteur évoque l'élaboration de bases de données prosopographiques et la conduite d'entretiens, dont on repère finalement peu les usages dans l'analyse. Il aurait été fécond d'en tirer plus fortement profit, en dépit des incontestables difficultés que peut susciter l'application de ces méthodes à l'objet d'étude. L'établissement de biographies collectives sur l'une ou l'autre des périodes traitées dans l'ouvrage aurait enrichi l'analyse statistique de portraits sociologiques qui apprécient l'homogénéité sociale et professionnelle des différents groupes engagés dans les deux partis communistes, en identifiant des parcours types ou en reconstituant la diversité de leurs trajectoires individuelles. Celle-ci aurait en outre pu être incarnée au travers d'entretiens qui donnent à voir des situations personnelles et permettent, plus particulièrement, de saisir comment logiques de position, i.e. les opportunités d'ascension, et logiques d'adhésion, i.e. les effets de la socialisation, se sont articulées en pratique dans la construction des carrières militantes au sein des 
partis communistes. Ces quelques remarques n'enlèvent toutefois en rien à la qualité de l'ouvrage, riche et original, dont la lecture est très stimulante.

Joo-Yup LeE, Qazaqlï, or Ambitious Brigandage, and the Formation of the Qazaqs : State and Identity in Post-Mongol Central Eurasia, Leiden-Boston : Brill, 2016, 238 p.

\section{Xavier HaLlez \\ CETOBAC (EHESS), Paris}

Joo-Yup Lee publie dans cette première monographie sa thèse soutenue en 2012 à l'Université de Toronto. L'objet de son étude est la transformation politique de l'Asie centrale post-mongole qui est regardée au travers du prisme d'un phénomène particulier dénommé qazaqlïq. L'auteur définit cette pratique en deux volets : une première manifestation qui est celle du « political vagabondage » ou pour reprendre le titre de l'ouvrage, « ambitious brigandage », consistant à : « running away from one's state or tribe and living the life of a freebooter in a frontier or other remote region »; et une projection politique de ceux qui entreprennent cette voie : "Qazaqlïq served as a stepping stone toward founding their own polities ». L'ouvrage peut se concevoir comme histoire des idées, histoire politique et étude orientaliste.

Un des atouts de ce livre est de s'appuyer sur un corpus de sources très larges, comprenant des textes arabes, persans, centrasiatiques, russes, occidentaux et chinois. Ces sources sont largement citées dans le texte, proposant un tableau très riche des multiples désignations usitées pour les populations d'Asie centrale. L'auteur ne néglige pas non plus les sources orales (légendes et généalogies) collectées essentiellement à la période tsariste par des Russes et des Kazakhs, mais cet ensemble reste limité à des éléments largement connus et publiés en russe. Les diverses éditions compilant l'orature kazakhe n'ont pas été utilisées. La dernière en date, éditée entre 2004 et 2014 (Qasqabasov S. (dir.), Babalar sözi : žüztomdyq (Les légendes des ancêtres en 100 volumes)), aurait renforcé le regard endogène. La bibliographie est abondante et les absences notables concernent les travaux d'Irina Erofeeva, historienne kazakhstanaise travaillant sur le khanat kazakh (Rodoslovnye kazahskih hanov i koža XVIII-XIX vv. (Généalogies des khans et des qožas kazakhs XVIII ${ }^{\mathrm{e}}$-XIX ${ }^{\mathrm{e}}$ siècles), 2003 ; Èpistoljarnoe nasledie kazahskoj pravjaščej èlity 1675-1821 gg. Sbornik istoričeskih dokumentov v dvuh tomah (Correspondances des élites régnantes kazakhes 1675-1821), 2014) et les ouvrages de Sandžar Asfendiârov publiés dans les années 1930 (Istorija Kazakhstana 
(Histoire du Kazakhstan), 1935 ; Prošloe Kazahstana v istočnikah i materialah (Le passé du Kazakhstan dans les sources et les documents), 1935-1936).

Le livre comprend deux parties, une première consacrée à la définition et à la description du phénomène de qazaqlïq et une seconde traitant de la construction de l'identité kazakhe dans le contexte de fragmentation politique de l'Eurasie centrale à partir du $\mathrm{XV}^{\mathrm{e}}$ siècle. La première partie ne traite pas directement du cas kazakh, mais s'intéresse à dresser un cadre pour son emploi. La qazaqlïq est présentée grâce à de multiples citations qui montrent les situations dans lesquelles cette terminologie fut employée. L'auteur nous offre un panorama complet des sources sur ce thème. Il expose de même les définitions élaborées par les historiens et les orientalistes depuis le XIX ${ }^{\mathrm{e}}$ siècle.

Cet exposé précis et minutieux lui permet d'établir la singularité du phénomène de qazaqlïq aussi bien dans le temps que dans l'espace. L'extension de la qazaqlïq est la résultante d'une fragmentation politique des ulus (apanages donnés aux fils de Gengis-khan) mongols commencée dès la fin du XIII' ${ }^{e}$ siècle, mais l'emploi du terme ne fut généralisé qu'à partir du $\mathrm{XV}^{\mathrm{e}}$ siècle. L'auteur en fait une démonstration parfaite à l'aide des sources timourides. Les histoires timourides n'emploient pas le terme de qazaq avant le $\mathrm{XV}^{\mathrm{e}}$ siècle, alors qu'ensuite cette terminologie est largement usitée. La qazaqlïq concerna spécifiquement les lignages gengiskhanides et timourides, héritiers des empires mongol et timouride. Les prétendants au pouvoir s'y référèrent et la pratiquèrent pour construire de nouvelles entités politiques en Eurasie centrale (le lignage gengiskhanide pour les Uzbeks et les Qazaqs et Tamerlan pour l'empire timouride) et même en Inde du nord (l'Empire moghol fondé par Babur, descendant de Tamerlan). Lee présente la qazaqlïq comme le principal moteur de cette reconfiguration politique.

Dans les deux chapitres suivants, le propos est élargi à des situations antérieures au XIII ${ }^{\mathrm{e}}$ siècle qualifiées de quasi-qazaqlïq et au cas particulier des cosaques. L'auteur montre l'existence de pratiques apparentées à la qazaqlïq chez un certain nombre de peuples turko-mongols (le kaghanat turk au $\mathrm{VI}^{\mathrm{e}}$ siècle ou le Liao occidental au $\mathrm{XII}^{\mathrm{e}}$ siècle). Bien qu'il n'ait pas été nommé ni formalisé auparavant, le phénomène proprement dit de qazaqlïq n'apparaît pas ex nihilo au moment de la dislocation de l'Empire mongol. Son originalité par rapport aux situations analogues des siècles précédents réside dans l'intensité du phénomène qui intègre dès lors le répertoire des pratiques politiques communes. Le cas des cosaques ou « kazaks » et notamment des Zaporogues illustre la large diffusion de la qazaqlïq en Eurasie centrale. L'apparition de la qazaqlïq a un rapport étroit avec les formes de dissidence des garnisons installées aux marges de l'Empire mongol. Ce contexte fait écho à celui rencontré au moment de la formation des groupes cosaques. L'auteur force toutefois sa démonstration en dessinant un hetmanat cosaque zaporogue, nouvelle entité politique fondée au XVI ${ }^{\mathrm{e}}$ siècle selon le modèle de la qazaqlïq et aux racines de l'Ukraine moderne. 
La principale remarque devant cette démonstration est une utilisation indifférenciée des sources endogènes et exogènes. Le discours porté notamment par les textes exogènes n'est pas abordé avec un regard critique quant à la description de pratiques ou de modes de vie qui ne sont pas forcément comprises ou admises. Cela est à noter pour les qualificatifs de pillages ou de brigandage comme pratique courante. La question de la notion et de la nature des entités politiques chez les nomades, qui est un sujet largement discuté ces dernières années, n’est pas non plus abordée.

La seconde partie s'intéresse à l'apparition de l'entité politique kazakhe et à sa construction dans une représentation de la qazaqlïq. Le propos est construit en trois points : la scission au XV siècle des Ouzbeks entre les "Shibanid Uzbeks » et les « qazaq Uzbeks », ces derniers devenant les Qazaqs ; l'existence de plusieurs désignations englobantes (Turk, Mongol, ulus de Jochi) dans lesquelles s’inséraient celles susnommées; et la cohésion entre le modèle de la qazaqlïq et les légendes sur le fondateur du khanat kazakh, Alash-khan.

Pour introduire le premier point, l'auteur nous dresse un tableau historique de la recomposition politique aux $\mathrm{XIV}^{\mathrm{e}}-\mathrm{XV} \mathrm{V}^{\mathrm{e}}$ siècles du Dasht-i Qypšaq (région allant de l'Ukraine au Kazakhstan) ou autrement dit l'ulus de Jochi. Un lignage jochide, qui sera dénommé Ouzbek, s'assura au XIVe siècle le contrôle de la partie orientale de cet ulus, correspondant à l'actuel Kazakhstan. Les fondateurs du khanat kazakh, Janibeg et Giray appartenant à un autre lignage jochide, se lancèrent dans une qazaqlïq au milieu du XV siècle contre le khan ouzbek. Lee défend l'idée que la sécession des Qazaqs des Ouzbeks et l'apparition d'une désignation Qazaq propre furent le produit de la prédominance du phénomène de qazaqlïq dans l'espace centrasiatique. De même, le khan ouzbek refoulé du Dasht-i Qypšaq oriental mena une qazaqlïq dont le résultat fut la conquête de la Transoxiane (approximativement l'Ouzbékistan actuel) et la permanence d'une désignation ouzbèke ou « Shibanid Uzbek » sur ce territoire. Le titre de khan attaché à la légitimité gengiskhanide (seul un descendant de Gengis-khan peut prétendre au titre de khan) et donc la forme des entités politiques centrasiatiques ne sont pas discutés. Il aurait été judicieux d'articuler le phénomène de la qazaqlïq à cet élément.

Le deuxième point est consacré au discours sur soi et aux désignations employées par les Centrasiatiques. L'existence d'une entité politique tant proprement ouzbèke que kazakhe est bien exposée, entre autres, avec la mention de l' «Uzbekistan » et du «Qazaqstan » dès le XVI ${ }^{\mathrm{e}}$ siècle. L'auteur s'attache aussi à définir les autres désignations englobantes usitées par les Centrasiatiques : turke, mongole et l'appartenance à l'ulus de Jochi. Il construit un modèle dans lequel les désignations s'emboîtent l'une dans l'autre : les Qazaqs et les «Shibanid Uzbeks »se rejoignant sous la désignation Uzbek ou l'appartenance à l'ulus de Jochi qui se fondent elles-mêmes dans celle plus large de Mongol et celle-ci s'insère à son tour dans la désignation globale de Turk. Il met en garde avec justesse contre la tentation d'assimiler la compréhension de ces 
désignations aux $\mathrm{XIV}^{\mathrm{e}}-\mathrm{XV}^{\mathrm{e}}$ siècles à celles contemporaines : il critique le fait que « in modern scholarly literature, Turk, Moghul [déformation de Mongol] and Uzbek are virtually used as synonyms for the Turkic-speaking peoples, the Mongolic-speaking peoples, and the ulus of the Abu al-Kharids or the inhabitants of modern Uzbekistan, respectively » (p. 138). Cette précaution se retrouve dans la distinction entre qazaq (personne ou groupe ayant adopté le mode de vie qazaq), Qazaq (en référence au khanat kazakh et élargi à la période coloniale russe) et Kazakh (désignation moderne depuis 1925 d'après Lee). Il n'explicite pas le choix de sa périodisation qui demande à être clarifiée. D'une part, la république soviétique autonome fut créée en 1920 et non en 1925. D'autre part, la distinction entre Qazaq et Kazakh semble indiquer une transformation identitaire avec l'attribution d'une république nationale. La construction nationale remodèle la communauté, mais cette caractéristique se vérifie pour toutes les « nations ». Les Kazakhs ont développé un discours national dès la deuxième moitié du XIXe siècle (Valikhanov cité dans le texte : « The vagrant-qazaqs, having already established a well-organized society, and in a certain sense, a nation » (p. 142)) et se sont toujours dénommés Qazaqs dans leur propre langue.

Le modèle Turk $>$ Mongol $>$ Uzbek $>$ Qazaq/Shibanid Uzbek pose problème et des questions importantes ne sont pas énoncées. Les sources utilisées pour établir ce modèle sont essentiellement exogènes, ce qui peut introduire un hiatus entre les termes englobants de ces sources et les noms auxquels se réfèrent elles-mêmes les populations. Les Chinois appelaient Turks ou Tujue uniquement les descendants des deux kaghanats turks, alors que le monde arabo-persan l'employait pour toutes les tribus nomades de l'Eurasie centrale. Les interactions entre la dénomination exogène et l'appellation endogène ne sont jamais mentionnées. De même, l'importance de la construction généalogique pour fonder la communauté et ses mécanismes propres n'apparaissent que brièvement. L'auteur utilise aussi des acceptations très différentes de la désignation Mongol pour démontrer la reconnaissance d'une identité mongole par les populations centrasiatiques : il entretient une confusion entre des khans, issus d'un lignage gengiskhanide et donc mongol, une soumission à la loi mongole (la Yassa établie par Gengis-khan) et le fait de se penser soi-même comme mongol ou mongol par l'intermédiaire de la généalogie. L'absence d'une analyse des formes du politique fait à nouveau défaut.

Le dernier point de la seconde partie du livre cherche à montrer le caractère central de la qazaqliq dans la construction identitaire des Qazaqs. Il expose les différentes versions de la légende d'Alash-khan, qui aurait fondé le khanat kazakh. Le nom d'Alash fut aussi dédoublé pour devenir l'ancêtre commun à tous les Qazaqs (Kazakhs) et fut utilisé sous différentes formes pour désigner les Qazaqs (Alty Alash, les six Alash, regroupant l'ensemble des tribus soumises au khan kazakh ; ou encore l'autonomie Alash entre 1917 et 1919). Les trois étapes de la qazaqlï se retrouvent dans ces légendes sur Alash-khan : «First, the separation of a prince and a group of people 
from their own tribe or state (...) Second, the Qazaq forefather as leading the life of vagabondage and brigandage, which is the basic characteristic of the qazaq way of life (...) Third, the transformation of the qazaq band into a new khanate » (pp. 152-153).

Cet ouvrage veut donner un élément de réponse à la question de savoir pourquoi : « unlike numerous other Inner Asian nomadic tribes and peoples that disappeared into the mists of history, the Qazaqs have been able to retain their group identity up to the present ». Malgré certaines réserves, Lee apporte un regard nouveau et pertinent sur l'histoire des Kazakhs et de l'Asie centrale post-mongole et intègre le phénomène de qazaqlï dans le répertoire des pratiques politiques de l'Eurasie centrale.

Un article de Lee, intitulé « Were the historical Oirats "Western Mongols" ? An examination of their uniqueness in relation to the Mongols » et paru dans le dernier numéro d'Études mongoles et sibériennes, centrasiatiques et tibétaines (47/2016), prolonge la réflexion sur les désignations présentes en Eurasie centrale et pose la question de savoir s'il est justifié de parler de Mongols occidentaux pour les Ö̈rats. Cet article ouvre une nouvelle perspective concernant la frontière entre un monde mongol et bouddhiste et un espace turk et musulman.

Adeeb KHALID, Making Uzbekistan: Nation, Empire and Revolution in the Early USSR, Ithaca: Cornell University Press, 2015, 415 p.

\section{Niccolò Pianciola}

Lingnan University, Hong Kong

Making Uzbekistan is the first monograph devoted to the core geographic area of early Soviet Central Asia - from 1917 to the early Stalinist period - that relies extensively on administrative documentation and literary production in Russian and Turkic languages. Adeeb Khalid is also the first historian to trace the biographical and political connections between Tsarist/early Soviet Central Asia and the late Ottoman Empire, helped by his ability to make use of the Turkish-language historiography.

Based on research in Uzbek, Russian, and British archives, the book follows a largely chronological order. The first chapter introduces the "cast of characters" ( $p$. 49): the members of the older generation of reformist intellectuals ("Jadids") born in the late nineteenth century, along with the first Soviet generation of Uzbek literary figures. Almost the entire first generation and many of the second were dead by the beginning of World War II, most of them killed during the Stalinist Great Terror. Other characters of the book are activists for different streams of the "cultural revolution" (p. 26), such as Central Asian women who battled for the redefinition of their place 
in society. As Khalid puts it, the book is thus also "an elegy for two lost generations of the Central Asian intelligentsia" (p. 26). This aim is handsomely achieved with the numerous excerpts of poetry, prose, and drama interspersed in the text, often finely interpreted. The "elegy" is functional to depicting the core issue of Khalid's study: the relation between culture and politics in revolutionary times, and the historical significance of a group of reformist Central Asian intellectuals whose influence was brought to the fore under the new regime.

Overlapping revolutionary projects remain at the core of Khalid's analysis. According to him, the significant coincidence of the "Jadid" intellectuals' and Bolshevik cultural and political agendas magnified the role of the former in early Soviet Central Asia. The center of the Jadids' "national project" was a "cultural revolution" bringing modernity and empowerment to their society in opposition to both the colonizers and their local opponents. Both the Jadids' and Bolsheviks' "projects of modernity" aimed to radically transform Central Asia: by the introduction of mass secular education, by liberating women from oppressive patriarchal social norms, by reforming land ownership, and by creating "national identities" (p. 2). The latter issue is the interpretative core of the book, a cultural and political trajectory thus summarized by the author: "the creation of Uzbekistan [in 1924] was the triumph of a national project of Central Asian Muslim intellectuals who had come to see themselves as Uzbeks" (p. 1). Abdurauf Fitrat (1886-1938) stands out in Khalid's book as the most influential intellectual force behind this project. Distancing himself from his earlier literary production in Persian, after 1917 he imagined a "Turkic" nation centered in Transoxiana based on the glory of Timurid military power and Chaghatay high culture. Fitrat also embodied the high point of the reformist intellectuals' political influence, since he was one of the ministers of the Bukharan People's Republic (1920-1924). Khalid places the revolutionary Bukharan political idiom firmly within "discourses of Muslim modernism", as they followed Ottoman models. Revolutionary Bukhara was the political incubator of Uzbek nation-building, brought to fruition in the context of the Soviet "multi-nationalizing" empire (pp. 286-290). Khalid describes Uzbek nation-building as the mirror process of Turkish nation-building. They both relied on the parallel rediscovery of a Turkist political discourse and its eventual ethnicization. Khalid concludes that "it is possible to think of Turkey and Uzbekistan as counterparts-as heirs to 'western' (Ottoman) and 'eastern' (Chaghatay) Turkic cultural and political traditions, each nationalized in the early twentieth century through intertwined but distinct discourses of Turkism" (p. 289).

On the one hand, Khalid underscores the biographical and political connections between Anatolia and Turkestan. Fitrat had, after all, studied from 1909 to 1913 in the Istanbul madrassa where Yusuf Akçura was teaching Turkic history (p. 40). Yet, on the other hand, Khalid is careful to emphasize that there was no such thing as a transnational "Pan-Turkist" ideology. He claims, instead, that the ethnicization of 
Turkestani and Bukharan progressive Muslim intellectuals' "political imagination" during the years of war and revolution took the form of a "Turkestan-centered Turkism" that "claimed the entire tradition of Islamicate statehood and high culture in Central Asia on behalf of the Uzbek nation" (p. 15). The leaders of the Bukharan People's Republic had no ambition of creating any common political entity going beyond the borders of the sedentary population of Transoxiana. This was the nation to be forged by the project of standardization of different Turkic dialects into an Uzbek language, the character of which should adhere as closely as possible to its Chaghatay linguistic "ancestor", thus formulating what Khalid calls the Chaghatayist "vision of the Uzbek nation" (p. 15). Central Asian intellectuals emerge as carriers of the benign form of nationalism, the postcolonial one, hence the exclusive use of the expression "national project" by Khalid, whereas the word "nationalism" is explicitly eschewed because of its negative connotations (not the least because the political police used it as a hammer during the bloody repressions of the 1930s).

As a consequence, the comparison between Chaghatayist and Turkish "Turkisms" leaves aside the fact that the latter briefly morphed into the ideology of a genocidal military-political elite during World War I. This is not to say that Khalid misses a darker, ethno-nationalist side of Uzbek nation-building (as he convincingly shows, there was none). However, this important difference between the "eastern" and "western" "Turkisms" is a point that begs further analysis. The more so, since Khalid underscores the power of early Central Asian Turkism insofar as it was as much a revolutionary discourse as it was an ethnonational one. This point allows him to explain eloquently why the Tajiks remained "a residual category" (p. 291): many Persianspeaking intellectuals of Central Asia were as much "committed to a Chaghatayist vision of Central Asia" as the Turkic-speaking ones, given the "fascination felt for Turkism by all modernist intellectuals in Central Asia, regardless of the language they spoke" (p. 292). This aspect is fully developed in his analysis of the "nationalterritorial delimitation" of 1924 and of the subsequent disputes between different groups of intellectuals that started to identify themselves with the Uzbek and Tajik nations.

The focus on the "progressive" urban intellectuals is, at the same time, a strong point and a limitation of the book. It provides a refreshing perspective to a history that often has been told only with reference to Bolshevik policies. However, Khalid's narrative does not give much space to alternative "national projects". The Uzbek-Chaghatayist outcome emerges, at least implicitly, as a foreordained result of the struggle of ideas among Transoxiana's intellectuals, given the absence of competing "Turkist" projects. Khalid describes the project of the Kazakh and leading Turkestani Bolshevik Turar Ryskulov as a "national anticolonial revolution" at which he arrived independently "using contemporary Bolshevik political language" (p. 110), but he underplays the significance of Ryskulov's Turkism, which appears to be quite prominent in his 
political activity, and different from Fitrat's Chaghatayism. Moreover, the focus on urban intellectuals and Central Asian Bolshevik leaders leaves in the background the political role of regional warlords, especially in Eastern Bukhara and the Ferghana valley. The intense negotiations between the Tashkent Bolsheviks and Madamin-bek, who commanded thousands of armed men in Ferghana, are not mentioned by the author. A final problematic point is the category "Jadidism" itself (defined as "an indigenous movement of modernist reform", p. 2), which is coming under increasing criticism by historians of Central Asian Islam such as Devin DeWeese, Paolo Sartori, and others. They point out that the reformist network of literati was much less coherent than the prevailing use of "Jadid" as a label for a "movement" would imply. On the issue of women's "liberation" for instance, Fitrat, Khalid's hero, defended existing patriarchal norms, namely polygamy. Moreover, the "national idiom" was not monopolized by "Jadid" intellectuals, since ulemas usually pinned under the "traditionalists" label, also made use of it in the revolutionary period.

These minor problems notwithstanding, this highly readable, rich, and passionate book succeeds in reviving a group of cultural and political figures who left a durable imprint on twentieth-century Central Asia. Khalid is the first scholar who convincingly shows how the new Soviet Uzbek culture, not unlike the Soviet Russian one, "emerged through a complex interplay between the new revolutionary state and indigenous cultural elites, which had their own understanding of what revolution and Soviet power were about" (p. 18). Moreover, the study manages to inscribe for the first time the events of early Soviet Central Asia in the larger Eurasian web of connections, especially through the Ottoman Empire, Persia, and Afghanistan. For these reasons, the book deserves high praise and will remain mandatory reading for any student of modern Central Asia, the early Soviet Union, and the wider Turco-Persian world.

Susanna Soojung Lim, China and Japan in the Russian Imagination, 1685-1922. To the ends of the Orient, New York : Routledge, 2013, $223 \mathrm{p}$.

\section{Iacopo ADDA}

\section{Global Studies Institute, Université de Genève}

Issue d'une thèse de doctorat, l'œuvre de Susanna Soojung Lim est une sorte de petite encyclopédie de la pensée russe sur la Chine et le Japon. De la première lettre envoyée en 1686 par l'empereur Mandchou Kangxi aux tsars Ivan V et Pierre le Grand jusqu'à la mort de Velimir Khlebnikov en 1922, la perception russe de ses voisins extrême- 
orientaux se forme et évolue à travers de nombreuses contradictions. Le but de l'auteure est de suivre cette évolution par le biais d'un parcours interdisciplinaire, qui articule l'analyse de la production littéraire à l'étude de l'histoire culturelle et intellectuelle de l'époque considérée. Cet effort ne vise pas seulement à renseigner le lecteur sur la façon dont l'Asie de l'Est était perçue par la société russe entre le $\mathrm{XVII}^{\mathrm{e}}$ et le $\mathrm{XX}^{\mathrm{e}}$ siècle. L'aspect sans doute le plus remarquable de l'œuvre de Lim est sa volonté de nous montrer dans quelle mesure l'Asie orientale a contribué à la définition, ou à la mise en question, de l'image de l'Empire russe dans la pensée de ses élites et de ses milieux culturels. Qu'il s'agisse de son identité nationale, de son statut impérial ou de sa légitimation historico-culturelle vis-à-vis des pays de l'Europe occidentale, l'Asie a constitué un point de repère important pour la Russie.

Par ailleurs, étant donné que la Russie, la Chine et le Japon ne s'inscrivent pas dans une relation d'interdépendance directe de type colonisateur/colonisé, l'auteure se retrouve face à la difficulté d'appliquer une analyse saïdienne stricto sensu à un orientalisme russe que de nombreux spécialistes considèrent comme atypique. Afin d'arriver au bout de sa recherche ambitieuse, Lim a rassemblé un corpus de textes de nature différente : des œuvres de sinologues, des œuvres littéraires, des poèmes, des romans de science-fiction, des essais philosophiques, des textes de politique étrangère, ainsi que des images. Il en découle une vision d'ensemble complète, encadrée dans une structure narrative cohérente et fluide.

Dans le premier chapitre, l'auteure suit les vicissitudes historiques qui ont fait se croiser la trajectoire expansionniste de l'Empire russe avec celle des Empires chinois et japonais. Si jusqu'au XVII siècle, la connaissance que les Russes avaient de la Chine passait largement par les steppes sibériennes, Pierre le Grand importa de l'Europe la passion pour la chinoiserie. En parallèle, les événements qui menèrent aux premiers contacts et traités bilatéraux russo-chinois sont bien esquissés, et la « découverte du Japon » est présentée comme une histoire passionnante d'explorateurs et de naufragés. L'attention de l'auteure se concentre surtout sur les mémoires de Vassili Golovnine, qui présentent une vision non stéréotypée du Japon et des Japonais.

Dans le deuxième chapitre, l'auteure se penche sur le règne de Catherine II et sur les interprétations multiples dont a fait l'objet l'idéal d'une Chine perçue en tant que berceau de l'absolutisme éclairé. Cette Chine, mythifiée par les représentants des Lumières en France, devient pour la première fois le miroir de la Russie impériale ; un miroir tantôt flatteur, tantôt frondeur, voire injurieux. C'est un passage fondamental dans l'analyse de Susanna Soojung Lim, car le « modèle chinois » ne quittera plus l'imaginaire poétique et intellectuel russe, tout en subissant des évolutions importantes.

À ce sujet, le titre du troisième chapitre est parlant : «Looking at China ; thinking of Russia 1790-1840 ». Il s'agit d'une période historique où la connaissance de la Chine s'enrichit en vertu du travail immense des premiers spécialistes de la 
Chine. Toutefois, les efforts de ces derniers sont frustrés par les premiers vents du Romantisme allemand, qui agitent la Russie à la fin du XVIII ${ }^{\mathrm{e}}$ siècle. La Chine, « une momie embaumée » selon Herder (p. 62), devient alors, pour les radicaux russes des premières décennies du XIX ${ }^{\mathrm{e}}$ siècle, le symbole de l'immobilisme et de l'inertie (kitajšina). Par la suite, Lim met en évidence les tentatives de synthèse d'Alexandre Herzen et d'Alekseï Khomiakov, mais l'idée de l'Est ne s'est pas encore fixée dans un concept bien défini. C'est pourtant à cette époque qu'en Russie, la notion d'un Est intérieur commence à s'opposer à celle d'un Est extérieur, lointain et, surtout, différent.

Le quatrième chapitre porte avant tout sur l'analyse de la « Frégate Pallas » (1858) d'Ivan Gontcharov. Cette source littéraire et historique permet à l'auteure d'entamer de nombreuses réflexions sur la façon dont Gontcharov perçoit l'Asie et le rôle de la Russie en Asie à un moment crucial de l'histoire. De fait, le choc de la guerre de Crimée éclipse le succès des Russes en Orient. À partir de ce moment, Lim remarque que la conception russe de l'Orient se fracture. D'une part, il représente l'espoir de l'avenir glorieux d'une Russie colonisatrice, à l'instar des puissances occidentales. D'autre part, vers la fin du XIX ${ }^{\mathrm{e}}$ siècle, l'Asie devient la source d'une inquiétude qui sera à la base de la crainte du « péril jaune ». Selon Lim, le « péril jaune » représente, en Russie, la perception d'un danger en provenance tant de l'Est que de l'Ouest. Par ailleurs, l'auteure nous montre dans quelle mesure, à partir d'Alexandre Herzen, plusieurs intellectuels ont associé l'idée de «sinisation » à l'idée de décadence de l'Occident. C'est le cas, par exemple, de la kitajšina que Fédor Dostö̈evski croit retrouver dans le prolétariat urbain de Londres (p. 93). Il va de soi qu'entre un Orient « dangereux » et un Occident « dégénéré », bon nombre d'intellectuels conservateurs attribuent à la Russie un rôle messianique et salvateur. En passant par les écrivains radicaux (tels que Mikhaïl Bakounine ou Nikolaï Tchernychevski), l'auteure conclut le chapitre sur les romans de science-fiction de Vladimir Odoïevski et de Grigori Danilevski. La comparaison qui en découle constitue un des passages les plus intéressants de l'œuvre de Lim, car elle offre au lecteur une preuve originale des différences de perceptions du danger qui existaient au sein de la société russe.

Le cinquième chapitre plonge le lecteur dans une sorte d' " âge d'or du péril jaune ». Une grande attention est dédiée à Vladimir Soloviev et à sa célèbre théorie du « pan-mongolisme ». Lim montre la relation qui existe entre une perception négative de la Chine et le «pan-mongolisme » en tant que résultat de la désintégration morale de l'Ouest. Elle remarque qu'au tournant du siècle, la Chine représentait un « [...] forum for a complex dialogue concerning the crisis facing Russia and the West » (p. 120). Entre la philosophie de Nikolaï Fedorov et le discours orientaliste très classique du Prince Esper Oukhtomski, Lim dessine les traits d'un courant intellectuel proposant le mythe d'une sorte de communauté de destins pour la Russie et la Chine. Il s'agit 
pourtant d'une narration en faveur d'une politique impériale, favorable à une poussée expansionniste vers de nouvelles régions asiatiques.

Le cœur du sixième chapitre est centré sur les réactions à la guerre russo-japonaise (1904-1905) au sein de la société russe. Les réactions souvent racistes de la presse sont contrecarrées par l'intérêt de Léon Tolstoï vis-à-vis de la Chine et de sa culture, ainsi que par son opposition à la guerre russo-japonaise. Lim remarque que celle-ci n'a pas suscité de nombreuses réactions dans le domaine littéraire. Toutefois, dans les pages que l'auteure dédie aux poètes symbolistes Valéri Brioussov et Dimitri Merejkovski, nous retrouvons ici encore les contradictions et les angoisses qui hantent les intellectuels russes, tiraillés par le dilemme éternel : Est ou Ouest?. Leurs propos apparaissent comme un mélange entre un impérialisme grossier (voire barbare), une réflexion portant sur un « péril jaune », tant intérieur qu'extérieur, et une admiration culturelle dérivant de leur japonisme. Lim réussit à mettre de l'ordre dans cette confusion intellectuelle de façon vertueuse et clôt sur une analyse détaillée du rôle joué par cet Orient mystérieux et ambigu dans le Pétersbourg d'Andreï Biély.

Il est certes possible de reprocher à Lim que sa conclusion n'en soit pas vraiment une. De fait, elle esquive le dur exercice de synthèse que son œuvre exigerait. Sa conclusion n'est en réalité qu'un dernier chapitre dédié principalement au poète futuriste Vélimir Khlebnikov. Les idées de Khlebnikov sont novatrices et fascinantes, puisqu'elles prônent une véritable union de la Russie avec l'Est (en particulier la Chine) contre l'oppression et la violence. Son Coup d'État à Vladivostok (1922) renverse décidément les clichés de l'orientalisme russe. Lim voit un certain lien entre cette œuvre et celle des premiers tenants de l'eurasisme, dont Nikolaï Troubetskoï. Toutefois, si d'un côté les eurasistes peuvent être envisagés comme des précurseurs de Frantz Fanon et d'Edward Saïd dans leur dénonciation de l'impérialisme culturel occidental, de l'autre, ils n'arrivent pas à se débarrasser complètement des traces de l'orientalisme russe dans leur réflexion.

L'œuvre de Lim contribue indubitablement à améliorer la compréhension du rôle joué par l'Asie orientale dans le discours russe. Son livre s'insère dans un domaine d'études très prometteur concernant l'orientalisme et l'impérialisme russes, dont le Russian Orientalism de David Schimmelpennick ${ }^{1}$ et La Russie et la tentation de l'Orient de Lorraine de Meaux ${ }^{2}$ constituent des exemples fascinants.

1 David Schimmelpenninck van der Oye, Russian Orientalism. Asia in the Russian Mind from Peter the Great to the Emigration, New Haven - Londres : Yale University Press, 2010 . 
Irina Muknina, Women and the Birth of Russian Capitalism, a History of the Shuttle Trade, DeKalb : Northern Illinois University Press, 2014, $173 \mathrm{p}$.

\section{Myriam DÉSERT}

\section{Université Paris-Sorbonne / UMR EUR'ORBEM}

Ce livre décrit le commerce pendulaire auquel se sont livrés, à partir de la fin des années 1980 et jusqu'à la crise financière de 1998, des millions de Russes, désignés en russe par le terme de «tchelnoki» (littéralement « navettes », comme celles des métiers à tisser). Travail de tissage aussi auquel se livre l'auteure, qui articule histoire orale (entretiens ex post avec des acteurs de ce commerce, collectés à Moscou, Khabarovsk et Krasnodar) et statistiques économiques pour dessiner une histoire matérielle de ce phénomène et une galerie de portraits, en même temps qu'elle nourrit la réflexion sur les processus sociaux et mentaux qui ont accompagné la sortie du système soviétique.

Ce phénomène fut central dans la transition postsoviétique. D'une part il a permis à des millions de personnes de traverser la période particulièrement difficile que furent les années d'effondrement du système soviétique, en leur assurant soit un moyen de subsistance, soit l'accès à des biens de consommation quotidienne qui n'étaient plus produits en Russie, à cause de la désorganisation économique. Quelques chiffres pour en donner l'ampleur : au milieu des années 1990, $41 \%$ de la population active était impliquée dans ce commerce (soit près de 30 millions de personnes) qui alimentait le marché à $75 \%$ pour les biens de consommation, $30 \%$ pour la viande et le poisson. D'autre part, il a modelé un large pan des représentations et pratiques sociales : forme de mobilisation adaptative spontanée, il a contribué à diffuser un apprentissage du « commerce ", enraciné dans la société, en contrepoint à la promotion top-down de l'économie de marché. D'où le titre de «naissance du capitalisme russe», illustrée par la citation empruntée à un entretien fait par l'auteure, qui définit ces acteurs comme « héros qui ont construit le capitalisme et ont appris aux Russes à faire du commerce ». L'autre volet du titre (« les femmes ») annonce quant à lui une approche genrée de la transition.

Les deux premiers chapitres de l'ouvrage sont chronologiques, montrant successivement la montée en puissance du phénomène, puis son apogée. Viennent ensuite deux chapitres visant à dresser le portrait socio-démographique de ce groupe, puis les difficultés que traversent ces femmes. Le dernier chapitre s'interroge sur leur devenir ultérieur.

Le principal apport de cette étude est une description très documentée des pratiques, soucieuse de rendre toute la matérialité des processus, qui affectent non seulement le mode de vie des personnes mais aussi les lieux (on mentionnera par 
exemple la description de l'ambiance dans le train Moscou-Pékin, axe important de ce commerce, ou celle de la transformation du stade de Varsovie en vaste foire au début des années 1990).

Rappelons le contexte de l'émergence du phénomène. Les années de perestroïka (fin des années 1980) ont vu une pénurie croissante, conséquence de la désorganisation galopante de la planification, en même temps que les premières libéralisations (la reconnaissance de l'initiative privée économique, la perméabilité relative des frontières, qui restaura une certaine liberté de circulation, le discours de reconnaissance des aspirations des consommateurs, la libération de celles-ci une fois les frontières entrouvertes). Ces mouvements suscitèrent rapidement des processus contraires : à l'euphorie initiale succéda en effet dans l'opinion publique une certaine hostilité (ressentiment contre les coopératives, enclaves d'économie privée, autorisées à partir de 1987, accusées d'augmenter la tension sur les ressources), qui favorisa une politique de taxation, dissuasive pour les nouveaux entrepreneurs. C'est parallèlement à cet échec de l'émergence d'une production de biens de consommation domestique que se développe le commerce pendulaire, qui répond à la fois à une demande des consommateurs et au besoin de pans de plus en plus larges de la population en quête de moyens de survie ou d'amélioration d'un quotidien très dégradé (" chômage technique » grandissant dans le contexte d'une activité économique ralentie, puis licenciements, dans les années 1990). C'est alors que se répandent les marchés de plein air où voisinent dans le plus grand désordre nourriture et pièces détachées d'automobiles, activité autour de laquelle se greffent rapidement racket et pratiques mafieuses.

Les premières années de la Russie postsoviétique sont caractérisées par l'auteure comme « âge d'or » d'un commerce pendulaire qui s'exerce dans un contexte de totale liberté jusqu'à la fin 1993 (après l'adoption d'une loi sur la « liberté du commerce »en janvier 1992). Plusieurs tableaux statistiques illustrent la nature des flux, suscités par les écarts entre les prix domestiques et « externes », de ce qui s'achète, comme de ce qui s'échange (car, du moins à l'origine, le troc l'emporte sur les transactions monétaires). Le lecteur apprend comment on peut tripler son salaire avec quelques cartouches de Marlboro ou des boîtes de barres chocolatées Snickers ; comment montres et appareils photos s'échangent contre cosmétiques, cigarettes et matériel électronique. L'auteure explique également les circuits favorisant ce « commerce» : les jumelages de villes au sein du bloc de l'Est, les responsabilités au sein de l'organisation des komsomols, entre autres, facilitent l'accès aux biens convoités. C'est ainsi que l'on peut s'assurer un revenu conséquent en rapportant trois paires de jeans de Pologne, pratique amorcée dès les années 1970. La cartographie des échanges s'élargit ensuite : du premier charter vers Istanbul, en 1992, à l'axe tardif (au milieu des années 1990) vers l'Inde et les Émirats, avec, sur toute la période, l'importance des flux de marchandises achetées en Chine. Sont également évoqués les circuits vers l'Espagne et l'Italie, tournés vers 
des vêtements de qualité, qui touchent un public beaucoup plus marginal, plus aisé, qu'il s'agisse des acheteuses ou des « vendeuses » (qui ont besoin d'une mise de fonds initiale pour se livrer à ce commerce). L'auteure s'applique à décrire au plus près la circulation des biens (on mentionnera par exemple le schéma des acteurs impliqué dans ce commerce en Turquie, p. 64).

Pour expliquer la féminisation de cette activité (exercée à $80 \%$ par des femmes), l'auteure avance des hypothèses enracinées à la fois dans les relations genrées telles qu'elles se manifestaient à la fin de l'époque soviétique (importance du taux de divorce et charges familiales reposant souvent de façon exclusive sur les mères) et dans des représentations essentialistes des femmes (porteuses du souci / du care, plus ouvertes à l'inconnu, habituées au cumul des tâches). À quoi s'ajoute le postulat que les femmes seraient plus douées que les hommes pour les échanges « informels»: dans des contextes caractérisés par le " marchandage ", les femmes auraient une capacité à mobiliser les ressources émotionnelles leur permettant de faire baisser le montant des fonds extorqués, par les douaniers par exemple (pratique qui suscite un récit coloré, rapportant les surnoms que les femmes donnent aux douaniers en fonction de leurs " préférences »). Les femmes sont également supposées avoir une meilleure perception des besoins et donc savoir mieux choisir les produits qui auront du succès. Cette sensibilité à la demande en fait des spécialistes du marketing avant l'heure.

Le profil dominant est celui de trentenaires, se sacrifiant pour assurer les études de leurs enfants ou l'accès aux soins de leurs parents, dans un contexte où éducation et santé sont de moins en moins des secteurs " gratuits », d'un bon niveau d'éducation (ce qui, dans la période, constitue un tremplin vers l'auto-entreprise).

Le chapitre 4, intitulé « le prix du succès », décrit ce qui est souvent une descente aux enfers, abondamment documentée. Comme partout dans le monde, le commerce transfrontalier attire les « entrepreneurs de violence » (l'auteure reprend ce concept et les analyses de la dynamique de partage de ce marché, faites par V. Volkov, Violent entrepreneurs). La santé de ces femmes est mise en danger, notamment par un usage des drogues et de l'alcool qui en entraîne plus d'une vers la toxicomanie.

Par ailleurs, leur activité, réputée « rémunératrice », contribue à la dégradation des relations de genre. Les hommes exigent rémunération pour aider au portage des biens « importés » dans les transports, les maris, se sentant humiliés par le différentiel de revenus qui s'instaure dans le couple, redoublent de violence familiale. De plus, de nombreuses femmes voient leurs enfants « placés », au nom de leurs longues absences.

La perception que ces femmes ont d'elles-mêmes oscille entre la honte et la fierté, entre la souffrance et le sentiment d'empowerment, la moitié d'entre elles renonçant à cette activité dès la première année, $70 \%$ des autres déclarant souhaiter l'abandonner. 
Une question centrale qui découle du titre donné à l'ouvrage est en effet de s'interroger sur le rôle joué dans l'avènement du capitalisme par des femmes qui sont plus souvent " entrepreneurs par nécessité » que par choix. L'auteure esquisse une discussion en convoquant les cadres théoriques de l'économie néo-classique (rationalité des choix) et ceux de l'économie institutionnelle, mais la dimension théorique est très marginale dans l'ouvrage et c'est bien plus dans la description des pratiques concrètes qu'est son apport, pratiques caractérisées par le principe du « learning by doing ». On découvre comment ces acteurs agissent dans un contexte de «marché sans le marché », comment les tchelnoki essaient d'utiliser leurs réseaux pour créer une sorte de marché « collectif», comment les autorités essaient de fabriquer du de jure à partir du de facto, ... et comment les agents du commerce pendulaire s'appliquent à contourner les tentatives d'encadrement et de régulation. Telle la pratique dite des « chameaux » qui consiste à « embaucher » une famille pour faire un voyage en Chine, en l'enjoignant de multiplier les couches de vêtements à son retour, afin de tromper les douaniers et d'échapper à la taxation.

En forçant le trait, on peut dire que le chapitre 5 («Que sont ces femmes devenues ») marque la disparition de celles qui ont constitué le sujet du livre. L'évolution du contexte macro-économique a modifié tant le marché de l'emploi que la demande des consommateurs (ce sont désormais les matériaux de construction, l'électronique et les voitures d'origine étrangère qui ont la préférence). Le commerce pendulaire a perdu de sa rentabilité et exige aujourd'hui de plus grosses mises de fonds, tandis que l'évolution de la législation sur les PME facilite la création de services de proximité. Seulement $10 \%$ des tchelnoki auraient poursuivi leur activité dans les années 2000, en changeant de profil, quelques membres de ce qui n'était finalement pas une communauté mais un groupe très hétérogène a connu le succès, certains autres continuent à participer de ce commerce, mais désormais comme salariés des premiers.

À partir de cas particuliers, l'auteure essaie d'identifier des paramètres favorisant la réussite mais elle arrive au constat qu'ils ne sont ni de genre, ni de niveau de formation et que ce qui est déterminant est la capacité à diversifier ses activités.

Si au final la démonstration du rôle des femmes dans la naissance du capitalismen'est pas vraiment convaincante, l'impact de ce commerce pendulaire dans la circulation des signes, la globalisation et l'«occidentalisation » des désirs, la construction de la distinction par le biais des labels et des " contre-façons de qualité » sont bien démontrés (p. 92 et ss.). Pourtant, le phénomène n'a pas complètement modifié les mentalités. Un sondage effectué en 2005 donne $38 \%$ des personnes interrogées le jugeant négativement, $37 \%$ le valorisant, les autres ne sachant qu'en penser. Résultat qu'il convient de relativiser en rappelant que les précurseurs de ce type d'activité dans les années 70 étaient unanimement stigmatisés comme «spéculateurs ». 
L'auteure, dans son approche empathiqe des femmes qu'elle a interrogées, se livre à une mythologisation de ses héroïnes et passe à côté d'autres processus qui ont accompagné la «naissance du capitalisme russe», tel le réemploi des savoirfaire de débrouille soviétique. Il n'en reste pas moins que cet ouvrage constitue un riche apport documentaire, illustrant l'inventivité des pratiques et la façon dont le commerce pendulaire a transformé l'espace social global, par-delà l'objectif de survie qui animait ses acteurs.

Grzegorz Rossoliński-Liebe, Stepan Bandera : The Life and Afterlife of a Ukrainian Nationalist. Fascism, Genocide, and Cult, Stuttgart : Ibidem-Verlag, 2014. 654 p.

\section{Éric Aunoble}

\section{Université de Genève}

Les événements qui agitent l'Ukraine depuis la fin 2014 ont vu les polémiques autour de Stepan Bandera (1909-1959) reprendre vigueur. Entre l'apparition du portrait du leader nationaliste sur le Maïdan contestataire et la dénonciation des «bandéristes » par les pro-russes, il est apparu comme une figure clivante. Était-ce un fasciste et un collaborateur ou un patriote, victime des soviétiques et des nazis ? On ne disposait d'aucune biographie sérieuse pour répondre. Issu d'une thèse, le travail de Grzegorz Rossoliński-Liebe est donc particulièrement bienvenu. Il s'inscrit dans la lignée d'études scientifiques sur le nationalisme ukrainien initiées depuis peu d'années ${ }^{3}$. Adossé à une impressionnante bibliographie, ce livre est principalement fondé sur des archives étatiques polonaises, allemandes et soviétiques. L'auteur a également mené ses investigations dans la mouvance nationaliste, aussi bien dans la documentation publique ou interne que parmi des acteurs survivants.

Le genre biographique impose au livre une construction classique. Un premier chapitre situe l'évolution du nationalisme ukrainien dans un contexte européen au début du $\mathrm{XX}^{\mathrm{e}}$ siècle qui voit se conjuguer revendications identitaires et schémas racialistes. L'incapacité à créer un État ukrainien à l'occasion de l'effondrement

3 Timothy Snyder, « The Causes of Ukrainian-Polish Ethnic Cleansing, 1943 », Past and Present, 2003, n 179, pp. 197-234. John-Paul Himka, « The Lviv Pogrom of 1941 : The Germans, Ukrainian Nationalists, and the Carnival Crowd », Canadian Slavonic Papers, June-September-December 2011, vol. 53, nn 2-3-4, pp. 209-243. Per Anders Rudling, « The OUN, the UPA and the Holocaust : A Study in the Manufacturing of Historical Myths », The Carl Beck Papers in Russian and East European Studies, 2011, n 2107. 
des empires (1917-1920) radicalise le nationalisme ukrainien vers la droite. Dmytro Dontsov, son principal théoricien, bien qu'évitant tout engagement direct, participe à l'acclimatation des idées fascistes en Galicie, par exemple en traduisant dès 1926 des extraits de Mein Kampf.

Le deuxième chapitre retrace la jeunesse de Stepan Bandera, élevé dans la famille d'un prêtre gréco-catholique qui avait activement soutenu la République populaire d'Ukraine de l'Ouest (ZUNR, 1918-1919) et son armée. Lecteur de Dontsov, l'adolescent réinvestit tout cet héritage politique en s'engageant précocement chez les scouts nationalistes Plast, puis dans l'Organisation militaire ukrainienne (UVO). Il trouve naturellement sa place dans l'Organisation des nationalistes ukrainiens (OUN), dès sa création en 1929, et ses années d'étudiant sont surtout des années d'activisme lui permettant de se constituer un réseau militant. Alors que la direction officielle de l'organisation - composée d'anciens - est rapidement contrainte à l'exil, Bandera est celui qui organise et radicalise la lutte sur le terrain, en Galicie.

Cette lutte prend la forme d'actions terroristes visant les ennemis de la nation ukrainienne : représentants des autorités polonaises et soviétiques, mais aussi Ukrainiens considérés comme des collaborateurs, tels un directeur d'école ou des militants récalcitrants de l'OUN. Néanmoins, c'est l'assassinat du ministre de l'Intérieur polonais Pieracki en 1934 qui a le plus de retentissement. Les procès qui s'ensuivent sont minutieusement décrits au troisième chapitre. Conformément à sa tactique révolutionnaire, Bandera les utilise comme tribune : il refuse de parler en polonais et encourage ses co-accusés à effectuer le salut avec le bras tendu, à la mode fasciste. Comme le pouvoir polonais cherche l'apaisement avec l'importante minorité ukrainienne du pays, Bandera sauve en définitive sa tête.

Condamné à la prison à perpétuité, il est libéré par l'invasion nazie de septembre 1939. Bandera reprend ses activités, sans risquer désormais la répression : il voyage librement en Slovaquie ou en Italie. Il rompt avec l'ancienne génération de leaders incarnée par Melnyk, et, dans l'esprit du Führerprinzip, il se proclame provydnyk (chef) d'une branche de l'OUN, vite appelée $O U N-b$ (« b » pour bandériste). L'organisation prépare la « révolution nationale ukrainienne » qui coïncidera avec l'offensive allemande : il s'agit de mettre en place un État totalitaire qui débarrassera le territoire national des populations allogènes (Juifs, Polonais...) et des traîtres (du communiste au libéral). Les nazis et les nationalistes collaborent donc aisément ${ }^{4}$, chacun poursuivant néanmoins son propre but. Le hiatus devient évident en juin 1941, quand, au grand dam des Allemands, l'OUN-b proclame l'indépendance ukrainienne dans Lviv tout juste conquise par la Wehrmacht : Bandera est arrêté début juillet. Il 
n'empêche que l'infiltration des nationalistes dans la police supplétive pro-allemande et leur participation aux premiers pogroms ressort bien de la politique définie par le provydnyk.

L'auteur retrace ensuite l'action de l'OUN-b puis de l'Armée insurrectionnelle ukrainienne (UPA) en Ukraine, alors même que Bandera est détenu au camp de Sachsenhausen de janvier 1942 à septembre 1944. Le statut de prisonnier du provydnyk doit-il alimenter la thèse d'un nationalisme ukrainien en lutte " contre les deux totalitarismes »? Les nazis retiennent Bandera dans un quartier du camp dédié à des prisonniers de marque qui ne connaissent pas les horreurs du travail forcé. Sa libération, sept mois avant la reddition de l'Allemagne nazie, correspond à la volonté nazie de réactiver les nationalismes antisoviétiques : Bandera intègre le Comité national ukrainien (UNK) proclamé au début 1945 à Weimar (la division SS Galicie devient ainsi formellement la $1^{\text {ère }}$ division de l'Armée nationale ukrainienne subordonnée à l'UNK).

Après la chute du nazisme, Bandera s'installe à Munich avec sa famille. Comme beaucoup de combattants nationalistes, il s'est fondu dans la masse des « displaced persons " pour échapper aux poursuites et, dès 1945, les autorités britanniques et le Vatican font de leur mieux pour leur éviter le rapatriement réclamé par les Soviétiques. La guerre froide rend Bandera utile aux Occidentaux qui espèrent trouver dans les débris de l'UPA non seulement le moyen de nuire aux Soviétiques mais surtout une source de renseignements sur place. Bien qu'ayant gommé les aspects les plus ouvertement fascistes de son discours, Bandera n'a pas changé. Il spécule assez cyniquement sur la probabilité d'une troisième guerre et cherche à purger son mouvement de toutes les oppositions. Ne pouvant les éliminer comme avant guerre, il se voit concurrencé dans la diaspora par d'autres groupuscules. Il perd le soutien des Américains, puis des Anglais, quand il devient évident que les Soviétiques ont annihilé les restes de la guérilla ukrainienne. L'homme assassiné en 1959 par un agent soviétique n'est plus un véritable acteur politique mais seulement un symbole.

C'est à ce titre qu'il survit et fait l'objet des trois derniers et passionnants chapitres. En URSS, Bandera est devenu l'archétype de l'ennemi et du traître, un peu comme Makhno avant-guerre. Nolens volens, les autorités soviétiques favorisent sa postérité en lui conférant la stature d'un opposant irréductible. Alors même qu'aucune de ses orientations politiques - du terrorisme en République polonaise à l'espoir d'une $3^{\text {e }}$ guerre mondiale, en passant par la collaboration avec les nazis - n'a permis l'affirmation nationale de l'Ukraine et a fortiori un mieux-être pour les Ukrainiens, il devient aussi l'étendard de la diaspora ukrainienne. Un certain nombre d'anciens militants nationalistes ont en effet œuvré au carrefour de la mémoire et de l'histoire pour façonner la figure héroïque de Bandera. Cela passe par la sous-estimation systématique des éléments fascistes de l'idéologie de l'OUN et par la réécriture de l'histoire, de la Seconde guerre mondiale en particulier. Comme l'a également montré 
Olha Ostriitchouk ${ }^{5}$, ce récit nationaliste diasporique est introduit en Ukraine après 1991, et prend l'ascendant sous la présidence Iouchtchenko qui décerna à Bandera le titre de « héros de l’Ukraine ».

Un tel résumé ne fait pas justice à l'érudition de Rossoliński-Liebe dont le livre est non seulement l'histoire d'une vie, mais aussi l'histoire de tout le mouvement nationaliste ukrainien. Synthétisant et élargissant les études parcellaires disponibles jusqu'à présent, son ouvrage éclaire d'un jour peu glorieux l'action du cardinal grécocatholique Cheptytsky et il fera aussi autorité sur la responsabilité - indéniable - de l'OUN-UPA dans les massacres des Juifs et des Polonais d'Ukraine entre 1941 et 1945.

En reconnaissant les éminentes qualités de l'ouvrage, on s'autorisera à en critiquer certains aspects. Comme individu, Bandera tend systématiquement à se dérober au lecteur. C'est sûrement le reflet d'une «personnalité totalitaire », tout à fait terne hormis sa pathologique volonté de pouvoir. C'est aussi le problème d'un livre qui se présente comme la biographie d'un homme sans assumer de devenir la monographie d'un courant politique : l'activité de l'OUN-UPA prend le pas par défaut, quand le « héros » du livre est prisonnier en Allemagne et forcé à l'inactivité. On peut également regretter que le texte publié soit trop resté dans le style de la thèse universitaire, avec ses précautions et lourdeurs dans l'énonciation et l'argumentation. Or le genre biographique est la seule production historienne qui soit lue au-delà des cercles spécialisés et les apports de cette recherche mériteraient d'être connus du public tant postsoviétique qu'occidental.

Viktor Stepanenko, Yaroslav Pylynskyi (eds) Ukraine after the Euromaidan. Challenges and Hopes, Bern: Peter Lang AG, International Academic Publishers, 2015, 272 p.

\section{Nataliya BoRYs \\ Global Studies Institute, Université de Genève}

Plus de dix ans après la « révolution orange » de 2004, l'Ukraine est à nouveau au centre de la politique européenne et mondiale. De nombreux ouvrages sont dédiés à « l'Euromaïdan » et à la place de l'Ukraine en Europe. Ukraine after the Euromaidan. Challenges and Hopes entend contribuer « à une meilleure compréhension de la

$5 \quad$ Olha Ostriitchouk, Les Ukrainiens face à leur passé : vers une meilleure compréhension du clivage Est-Ouest, Bruxelles : Peter Lang, 2013. 
transformation complexe en cours en Ukraine » (p. 9) et souhaite « explorer les divers facteurs et raisons qui ont conduit à l'Euromaïdan ukrainien » (p. 14).

Cet ouvrage, fruit d'un séminaire suisse-ukrainien organisé en juin 2014, présente les contributions d'une équipe de chercheurs, la plupart ukrainiens. Venant de différents horizons et régions d'Ukraine, ces chercheurs visent à « explorer les raisons et les facteurs sociaux, politiques et culturels, qui ont provoqué l'Euromaïdan et la transformation du pays dans sa dimension nationale et régionale, [...] ainsi qu'à analyser les nouveaux défis de réformes auxquels le pays est confronté » (p. 9).

L'ouvrage se compose de cinq parties qui couvrent thématiquement le caractère multidimensionnel de l'Euromaïdan. Dans la première partie, The Euromaidan and Ukraine's Revolution : Politics, Democracy and Civil Society, Viktor Stepanenko examine le Maïdan comme un processus complexe et interconnecté où le mouvement de protestation fut la «tentative la plus radicale de désinstitutionalisation de la politique postsoviétique depuis $1991 »$. Les manifestants ont construit « de nouvelles institutions, des règles et des valeurs qui ne sont plus postsoviétiques » (p. 30). Mykola Riabchuk et Andrej Lushnycky interprètent le Maïdan comme une révolution postcoloniale, principalement réalisée par la classe moyenne (p. 51). Andriy Portnov et Tetiana Portnova reconstituent la chronologie des événements les plus importants de Maïdan de novembre 2013 à février 2014. Ils concluent que l'intervention russe et la guerre en cours « ont renforcé la formation de la nation politique » (p. 71) et que « la thèse d'une identité nationale ukrainienne 'faible' est non seulement conceptuellement incorrecte, mais analytiquement inutile » (p. 71). Petro Burkovskyi et Olexiy Haran analysent les attitudes populaires envers « le choix européen » dans les sondages d'avant et d'après Euromaïdan. Ils font valoir que la Russie a émergé comme la principale menace à la souveraineté et à l'intégrité du pays, en particulier dans le Sud et dans les régions de l'Est. Yuriy Shveda referme cette partie en essayant de placer l'Euromaïdan dans le contexte de la théorie sociale de la révolution, et il tente de répondre à la question suivante : «L'Euromaïdan peut-il être qualifié la révolution sociale ? ». Son argument est que si la « révolution orange » de 2004 fut un succès inachevé, l'Euromaïdan a été « complet et réussi » (p. 93).

La seconde partie du volume, intitulée Ukraine's Revolutionary Challenges in the European and the Global Contexts, combine des articles portant sur le contexte international des événements. Sergiy Fedunyak et Sergiy Glebov placent la révolution ukrainienne dans le système post-bipolaire et examinent son impact au niveau régional. Pour Fedunyak, l'Ukraine a créé un précédent pour quitter la sphère d'influence russe, et elle incite ainsi des élites politiques d'autres pays postsoviétiques à faire de même » (p. 99). Glebov énumère les arguments pour débattre de « la nouvelle période postpost-bipolaire » (p. 105), et Iryna Maksymenko se demande si la neutralité est une solution pour la sécurité de l’Ukraine (p. 116). 
Dans la troisième partie, les auteurs analysent les questions sociales, économiques législatives et humanitaires. Valentyn Malynovskyi étudie la réforme de l'autonomie locale, tandis qu'Olexander Kopelynko et Olexander Kostylyev analysent la question de la décentralisation du pouvoir dans le contexte de la réforme constitutionnelle en Ukraine. Ils la saluent, tout en soulignant qu'elle est « un sérieux défi pour les législateurs ukrainiens et les experts juridiques » (p. 143). Olexiy Pozniak soulève la question importante de la transformation démographique du pays dans le contexte de l'annexion de la Crimée et du conflit dans le Donbass, alors qu'Olexander Branovskyi analyse les réformes économiques.

Dans la quatrième partie, intitulée Regional and Ethno-Cultural Dimensions of the Ukraine's Transformation, les auteurs se penchent sur les changements ethnoculturels et régionaux dans le contexte de l'Euromaïdan. Olexander Vyshniak étudie les résultats d'une enquête de 2014, qui montre que la grande majorité des Ukrainiens soutient l'idée d'un pays uni (p. 177). En effet, seulement $6 \%$ des personnes interrogées disent souhaiter se séparer de l'Ukraine. Sa conclusion est « qu'il n’y a pas de raisons internes évidentes pour le séparatisme dans toutes les régions du pays, y compris en Crimée et dans le Donbass » (p. 178). Ilya Kononov et Svitlana Khobta analysent un sondage d'opinion effectué au printemps 2014 dans le Donbass et à l'Ouest du pays. Ils résument le programme d'enquête sociologique « L'Est et l'Ouest de l'Ukraine », sans toutefois donner les résultats de l'enquête, ni les profils des répondants : « la plupart des personnes résidant dans le Donbass soutiennent le projet de restauration de l'identité internationaliste proto-soviétique, qui est de surcroît largement dépourvu de connotation nationale ». Maïdan est considéré comme le résultat des luttes des groupes au pouvoir » (p. 189), tandis que les habitants de l'Ouest du pays voient en Maïdan « la continuation de la révolution nationale » (p. 189). Sergiy Danylov analyse le fonctionnement des institutions nationales des Tatars de Crimée depuis l'annexion russe. Sergiy Klymovskyi tente de répondre à la question de savoir si le soulèvement du Donbass était une révolte populaire ou un putsch, en cherchant ses raisons dans l'histoire particulière de la région. Il soutient que le « communisme à la Donetsk » est formé de différent éléments : le nationalisme local, l’Église orthodoxe du Patriarcat de Moscou, la version soviétique de la paix sociale et le culte des héros de l'Union Soviétique » (p. 205).

La dernière partie du livre, Language, Media and Culture under Transformation, permet de comprendre la politique linguistique du pays et son bilinguisme (Yaroslav Pylynskyi), la guerre des symboles (Olexander Shulga) et l'art de la révolution (Natalia Moussienko).

L'un des mérites principaux de cet ouvrage est d'offrir un aperçu des points de vue des chercheurs ukrainiens, cette vision de «l'intérieur » qui manque tant à l'Occident, puisque la plupart des ouvrages consacrés à l'Ukraine sont écrits par des chercheurs occidentaux. Certes, cet ouvrage exprime parfois une vision très pro-européenne, pro- 
ukrainienne et parfois très " patriotique ». Ainsi, par exemple, les Ukrainiens sont dépeints dans l'introduction comme des Européens libres d'esprit : « malgré l'impact corruptif de la longue domination impériale de la Russie et de l'héritage soviétique, les Ukrainiens conservent les vertus de la dignité, de la liberté et de la justice. Ils chérissent leur amour pour l'indépendance et les droits individuels » (p. 11). L'Ukraine appartient à l'Europe, à ses traditions, à son histoire. Pour les auteurs, il y a une continuité entre le passé européen de l'Ukraine et l'Euromaïdan : Maïdan était « tout à fait naturel et logique », une continuation dans l'histoire du pays (p. 12). Le choix du terme « Euromaïdan » au lieu de « Maïdan », et de la langue ukrainienne en tant que « symbole du choix européen » (p. 228), est éloquent. De surcroît, la démocratie est vue par les auteurs de l'introduction comme une composante intégrale des Ukrainiens depuis le Moyen Âge. Certaines périodes historiques « pro-européennes » et proukrainiennes se chevauchent dans l'histoire ukrainienne, comme l'époque de la Rous de Kiev, la période des Cosaques du XVII ${ }^{\mathrm{e}}$ siècle ou le début du $\mathrm{XX}^{\mathrm{e}}$ siècle (p. 12).

Il y a en revanche comme une sorte de mépris pour l'Homo sovieticus de l'Est du pays et pour les Russophones, qui sont considérés par certains auteurs comme inaptes au changement. Par exemple, en analysant les sondages ukrainiens, Riabchuk et Lushnycky affirment que « pour les Russes et les Russophones, il était beaucoup plus facile d'intérioriser l'idéologie soviétique que pour les Ukrainophones », tandis que « les Russes ethniques ont tendance à regretter davantage l'effondrement de l'Union soviétique » (p. 32). En 2015, Riabchuk affirmait d'ailleurs dans une interview qu'il aimait « la nouvelle Ukraine, sans le Donbass et la Crimée $»^{6}$. Un autre auteur affirme que le Donbass est perdu pour l'Ukraine, parce que là-bas, « le projet proto-soviétique domine, tandis que l'Ukraine occidentale est véritablement européenne » (p. 190).

Les contributions de cet ouvrage sont assez inégales. Certaines d'entre elles sont basées sur des sources Internet et sur des sondages, tandis que d'autres sont le résultat d'un travail plus élaboré, avec des sources plus fiables et une bibliographie. La plupart des auteurs étant des spécialistes des relations internationales, l'analyse culturelle et historique fait défaut.

La crise continue et l'avenir du pays n'est toujours pas clair. Cependant, comme les contributeurs le mentionnent, Maïdan a apporté de nouvelles opportunités pour le renouveau du pays, y compris pour les chercheurs. Comme le disent Denis Dafflon et Nicolas Hayoz : « la révolution de Maïdan ouvre une nouvelle ère de réflexion sur la relation entre les citoyens et l'État, sur l'identité nationale et le passé de l'Ukraine ». Indéniablement, ce recueil est un précieux outil pour comprendre la dynamique de Maïdan de l'intérieur. nova-ukraina-bez-donbasu-i-krymu-podobaietsia-meni-bilshe (consulté le 10 février 2017). 
Thomas Chopard, Le Martyre de Kiev - 1919. L'Ukraine en révolution entre terreur soviétique, nationalisme et antisémitisme, Paris : Vendémiaire, 2015, $285 \mathrm{p}$.

\section{Éric AunOBLE}

\section{Université de Genève}

À l'approche du centenaire de la Révolution russe, on ne peut que constater le retard persistant de l'historiographie française dans ce domaine et particulièrement en ce qui concerne la guerre civile. Pendant longtemps, la seule histoire disponible en français était celle du défunt militant d'extrême-droite Dominique Venner? . Ultérieurement, Jean-Jacques Marie a fait mieux que de rééquilibrer le paysage éditorial. En brossant le tableau des conflits entre Rouges, Blancs mais aussi Verts (bandes paysannes) à partir de la documentation exhumée après 1991, il a fourni une introduction utile et vivante ${ }^{8}$. Toutefois, l'aspect de la question qui a connu un véritable renouvellement historiographique est celui des violences, avec le courant initié par Nicolas Werth. Il reste qu'en intitulant sa contribution au fameux Livre noir du communisme « Un État contre son peuple », il présentait les événements de 1917 à 1922 moins comme des affrontements que comme un processus unilatéral de répression?.

Tout en s'inscrivant dans cette lignée, le livre de Thomas Chopard élargit la perspective en retraçant l'ensemble des antagonismes qui ont agité la région de Kiev en 1919. Travaillant à une thèse sur les violences contre les populations juives d'Ukraine de 1917 à 1924 (thèse qu'il a depuis soutenue avec succès), Chopard maîtrise les sources et s'appuie ainsi sur un vaste corpus d'archives soviétiques conservées à Kiev et à Moscou, complété par celles des organisations juives. Le choix d'évoquer Kiev est judicieux car la ville est à l'épicentre du conflit : elle change de mains neuf fois entre janvier 1918 et mai 1920. L'an 19 voit se succéder les nationalistes ukrainiens de Petlioura, les bolcheviks puis les troupes blanches de Dénikine, avant la victoire quasiment définitive des Rouges en décembre. En culminant avec une vague de

7 Dominique Venner, Les Blancs et les Rouges : histoire de la guerre civile russe, 19171921, Monaco : Le Rocher, 2007 (1 1 ère éd. 1981).

8 Jean-Jacques Marie, Histoire de la guerre civile russe, 1917-1922, Paris : Taillandier « Texto », 2015 ( $1^{\text {ère }}$ éd. 2005).

9 Nicolas Werth, «Un État contre son peuple. Violences, répressions, terreurs en Union soviétique ", in Stéphane Courtois et al., Le Livre noir du communisme : Crimes, terreur, répression, Paris : Robert Laffont « Bouquins », 1998 (1 ${ }^{\text {ère }}$ éd. 1997), pp. 40315. 
pogromes d'une cruauté sans précédent ${ }^{10}$, cette année marque assurément le pire moment de la guerre civile.

Après avoir fait le portrait d'une ville multiethnique, Chopard entreprend d'écrire une « histoire au ras du sol » de l'année terrible. La « ville convoitée» est un enjeu pour des belligérants qui entendent « conquérir et administrer » (p. 23). La conquête est le résultat d'opérations militaires qui terrorisent la population. Elle sera ensuite soumise aux exactions des troupes victorieuses, exactions prenant le caractère d'une vengeance sur les représentants des autorités déchues. La prise en main de l'administration locale, avec un subtil dosage d'épuration et de recyclage du personnel, est effective comme affirmation d'un pouvoir et elle permet la prise de mesures idéologiquement symboliques. Par contre, elle échoue à remettre en ordre de marche les infrastructures utiles à la population.

La ville est entourée « de campagnes en armes » qui font l'objet du deuxième chapitre. Leur contrôle est fondamental pour les prétendants au pouvoir, mais la dynamique d'armement et de rébellion initiée en 1917 s'est renforcée l'année suivante contre l'occupant allemand. La politique agraire des bolcheviks braque la paysannerie et radicalise son rejet de tout pouvoir central. Cela favorise l'atamanchina, l'émergence de chefs de bandes armées, tels les tristement célèbres Zelenyi ou Struk. Dans cette atmosphère délétère, « on commençait à trouver que les Juifs étaient de trop » (p. 87) et Chopard décrit minutieusement la mécanique pogromiste dans quelques localités. Ces troubles à la campagne se soldent par la disette en ville qui pousse à son tour les pouvoirs en place à vouloir resserrer leur contrôle sur l'économie urbaine et rurale : c'est un cercle vicieux.

Les deux chapitres suivants sont consacrés aux outils répressifs des bolcheviks, la Tchéka et le système concentrationnaire (pp. 112-172). Concernant le " glaive et bouclier du Parti », l'auteur en rappelle l'histoire avant de dessiner le portrait sociologique des tchékistes de Kiev : de très jeunes hommes, autant issus de la petite bourgeoisie de la plume et de l'échoppe ${ }^{11}$ que de la classe ouvrière, et tous citadins en phase d'ascension sociale. Leur expérience des guerres et leur soif de promotion expliquent d'après l'auteur leur absence de scrupules, laquelle est favorisée par un cadre légal lâche sinon incitatif. Les prises d'otages, les arrestations et les exécutions sommaires se généralisent au confluent d'intérêts individuels et de la crainte bien réelle de voir s'effondrer le pouvoir communiste. Le camp de concentration

10 Lidia Miliakova (dir.) et Nicolas Werth, Le Livre des pogroms. Antichambre d'un génocide. Ukraine, Russie, Biélorussie, 1917-1922, Paris : Calmann-Lévy - Mémorial de la Shoah, 2010.

Souvent juifs dans ce cas. 
que les bolcheviks ouvrent à la périphérie de la ville ${ }^{12}$ voit la logique d'isolement prophylactique se coupler avec la volonté d'exploitation du travail des détenus. Les conditions de détention dépendent néanmoins largement de la personnalité du commandant du camp.

L'auteur revient ensuite sur la vague de pogromes de l'été 1919, essentiellement sous l'angle des exactions militaires. Il rappelle « la politique antisémite des armées antibolchéviques » (p. 173), dont une des caractéristiques est « le travail forcé des [Juifs qui] se maintient à une grande échelle, comme au temps de l'armée impériale » (p. 168). Si le ressentiment contre les Juifs existe aussi parmi les soldats rouges, il se traduit très peu en actes grâce à « l'encadrement soviétique qui se montrait inflexible avec un antisémitisme assimilé à de l'indiscipline » (p. 181). La fin du pouvoir bolchevique à Kiev voit s'ouvrir une nouvelle phase de violences ${ }^{13}$ où l'antisémitisme se conjugue facilement à l'anticommunisme. La domination blanche est scandée par trois vagues de pogromes en ville, lors de leur arrivée fin août, au moment de la médiatisation des « horreurs de la Tchéka » dans des rituels de deuil collectif en septembre et surtout quand ils enregistrent leurs premiers reculs en octobre. À tous les meurtres perpétrés au long de l'année, il faut encore ajouter la mortalité résultant des épidémies pour comprendre ce qui rend « la vie fragile » (p. 215 et ss.) et explique le bouleversement des normes morales et des comportements.

L'intérêt que représente cette monographie n'empêche pas d'en discuter certains choix et avant tout celui du cadre conceptuel pour envisager la guerre civile. Chopard ouvre son livre par cette description :

En 1919, tandis que l'Europe recouvrait une paix précaire, les débris de ses empires s'enfonçaient dans une nouvelle guerre. Aux frontières occidentales de l'ancien empire russe, où la révolution de 1917 achevait de dissoudre l'emprise des capitales impériales, des souverainetés nouvelles s'étaient esquissées (p. 7).

En conclusion, l'auteur oppose la « stigmatisation sociale, politique et ethnique » observable en URSS au « deuil collectif (...) matérialis[é] dans les pays occidentaux [par] les figures du soldat inconnu ou les monuments aux morts » (p. 237). Pour penser la violence, la sortie de la guerre à l'ouest de l'Europe est l'unique référence, la Révolution russe apparaissant comme un simple produit dérivé du conflit et surtout comme un écart à la norme.

12 Ils ne sont ni les premiers ni les derniers à faire usage de ce moyen de coercition, mais, d'après l'auteur, ils le systématisent.

13 Il faut noter que les symboles de l'ukrainité sont également visés dans un élan proprement réactionnaire. 
Comme le récit est de plus centré sur l'an 19, la dynamique propre qui anime l'empire russe depuis février 1917 est ignorée $^{14}$. Envisager la guerre civile en la coupant des processus politiques et sociaux qui la provoquèrent déforme nécessairement la perspective. On entrevoit avec l'exemple des guérilleros paysans ou des tchékistes de Kiev que la position occupée par tel ou tel en 1919 dépend souvent de ses engagements de 1917, voire de 1905 ( $c f$. p. 121 et p. 71). La mobilisation des individus en fonction de leur appartenance sociale et / ou nationale et de leur conscience politique s'était en effet traduite, après la chute du tsarisme, par l'organisation d'appareils politicomilitaires et ces appareils continuent de se nourrir de l'exacerbation des conflits. Ils représentent peut-être une perspective de promotion individuelle et sûrement l'espoir d'une protection dans une période troublée, mais ils incarnent surtout la possibilité vécue par les acteurs de refonder l'ordre social, de remettre le monde dans l'axe considéré comme prioritaire (au choix celui de la Russie, de l'Ukraine, du Prolétariat...).

Un tableau fidèle et complet de la guerre civile nécessiterait de décrire non seulement les appareils répressifs, mais aussi les institutions politiques et sociales, ainsi que les relations que les individus nouent avec les unes et les autres. Dans ce livre, conformément à son titre insistant sur le martyre, la population n'est présentée qu'en position de victime des pouvoirs (et surtout de celui qui s'avéra le plus efficace, le pouvoir bolchevique). On en reste, malgré un remarquable travail sur les sources, au schéma réducteur d'" Un État contre son peuple».

Ioulia SHuKAn, Génération Maïdan, vivre la crise ukrainienne, La Tour d'Aigues : Éditions de l'Aube, 2016, 208 p.

\section{Anne Le HuÉrou}

\section{Université Paris Nanterre}

Restituer près de deux ans de travail de terrain au plus près des acteurs des bouleversements qui secouent l'Ukraine depuis fin 2013 dans un ouvrage de 200 pages : Ioulia Shukan, chercheuse et enseignante à l'Université de Paris Nanterre, auteure de nombreux travaux académiques sur le monde post-soviétique, en particulier la Biélorussie et l'Ukraine, a conçu ce projet rapidement après avoir commencé à

14 L'auteur a traité de la période précédente dans : Thomas Chopard, « De la guerre mondiale à la guerre civile. L'occupation austro-allemande de l'Ukraine en 1918 », Hispania Nova, 2015, n¹3, pp. 218-231 (https ://amnis.revues.org/2444). 
suivre les acteurs de la crise ukrainienne. D'abord sous la forme de carnets de terrain publiés au fil des séjours sur un blog ${ }^{15}$, les premières observations d'une spectatrice engagée par sa présence même sur place, confrontée directement aux morts du Maïdan en février 2014, vont former peu à peu la matière d'un ouvrage qui a pour ambition de présenter à un large public les ressorts de l'engagement d'une " génération ». Tout en bénéficiant des notes et impressions prises sur le vif, l'ouvrage est publié à distance des événements, et constitue un ensemble que l'auteure a mûri au fil de ses voyages et de ses rencontres.

L'ouvrage, divisé en neuf chapitres et un épilogue, et présenté par l'éditeur comme un « document », se déroule selon une construction à la fois chronologique et thématique qui suit les grandes étapes de la crise ukrainienne, depuis les prémices de l'engagement sur le Maïdan, en novembre 2013, jusqu'aux reconfigurations complexes et parfois douloureuses qui suivent, déplaçant le centre de gravité des événements de Kiev vers le conflit armé à l'est.

Omniprésente dans les récits et l'imaginaire des révolutions arabes de 2010-2011, la notion de dignité revient souvent, dans les récits des personnages de Génération Maïdan. Dignité revendiquée face à la corruption omniprésente dans la vie quotidienne comme dans la vie politique; dignité bafouée après l'abandon en novembre $2013 \mathrm{du}$ projet d'association avec l'Union Européenne ; dignité de la résistance qui s'impose après les premières violences policières du 30 novembre et qui fait basculer la mobilisation.

Le paroxysme des journées de février 2014 est au cœur de l'ouvrage, avec la mise à nu de la violence qui soudain sature le récit. Amorcé par la répression brutale de la manifestation du 30 novembre 2013, le basculement de la mobilisation se cristallise début 2014, lorsque les premiers morts en janvier suscitent l'organisation de groupes d'autodéfense, lorsque la répression devient meurtrière, lors des journées tragiques des 18-20 janvier - plus de 100 morts parmi les manifestants, 13 parmi les policiers - accélérant la chute du régime de Ianoukovitch qui prend la fuite le 22 février. Les citoyens mobilisés qui racontent « leur » Maïdan ne sont ni des caciques de l'opposition, ni des militants de cette extrême droite nationaliste, en effet présente mais minoritaire, mais souvent érigée en responsable principale des affrontements, voire en instigatrice d'une prise de pouvoir illégitime. Le récit de ces journées permet de faire ressortir les ressorts intimes de l'engagement, les moments où les trajectoires basculent, à la faveur d'un contexte très mobile favorisant les prises de conscience et emportant les décisions. Par exemple, celle de David, entrepreneur prospère dans les technologies du Web, qui en quelques jours passe de l'envie de quitter la région de

15 «Citoyens ordinaires et processus politiques en Ukraine » (https://carnetsdeterrain. wordpress.com/). 
Mykolaïv, où on le somme au printemps 2014 de « choisir son camp », à l'engagement parmi les bénévoles qui vont « infiltrer » le ministère de la Défense pour apporter leur contribution à l'effort militaire. On retrouve dans ses réflexions les propos entendus ou recueillis lors de reportages, enquêtes, documentaires, auprès de très nombreux autres Ukrainiens, et notamment ceux qui vont s'engager comme volontaires dans des bataillons armés - une dimension que Ioulia Shukan n'aborde pas, à dessein, pour laisser la place aux autres formes d'engagement.

Participer à l'élan patriotique, suppléer aux carences de l'État, lutter contre la corruption présente partout dans ses rouages et notamment dans l'armée : c'est autour de ce triptyque que s'engagent les bénévoles dans cette seconde période, après la chute de Ianoukovitch, alors que s'engage une véritable guerre à laquelle l'armée n'est pas du tout préparée, tandis que tous les rouages de l'État sont à reconstruire. La mobilisation des bénévoles permet de déplacer le regard de Kiev vers les régions, celle où la guerre s'invite sous la forme de milliers de déplacés arrivant dans la gare de Kharkiv, de soldats blessés entassés dans des hôpitaux qui manquent de tout ; celles où les déplacées arrivent par centaines de milliers des régions de l'est et de Crimée.

Les déchirements de l'après-Maïdan ne sont pas passés sous silence, notamment le sort des personnes déplacées, qui va mobiliser de nombreux bénévoles mais aussi susciter des réactions hostiles qui soulignent en filigrane les tensions sociales et politiques de la société ukrainienne. On portera une attention spéciale pour le chapitre 7, le plus intime, et l'un des plus bouleversants, dont l'écriture même révèle l'impérieuse nécessité. D'une histoire singulière, le récit des trajectoires dramatiquement divergentes de deux frères emportés par les relations entre l'Ukraine et la Russie - Maria avait deux enfants, l'un était rouge et l'autre blanc... chantait J. Ferrat à propos de la Guerre d'Espagne -, dit l'histoire de milliers de familles, en Ukraine et en Russie durablement déchirées par les choix faits pendant cette crise. Ce chapitre est aussi intéressant pour ce qu'il met en relief de la forme de cet exercice. Si l'auteure, à l'exception d'une brève présentation dans l'introduction et de rares moments où le contexte a besoin d'être précisé, s'efface au profit de ses personnages, elle réapparaît ici et permet de comprendre un peu mieux encore la sensibilité manifestée envers les « citoyens ordinaires ».

Au-delà de ses grandes qualités intrinsèques, pourquoi un ouvrage se présentant d'emblée comme « non académique », laissant délibérément de côté les notes de bas de page et l'appareil théorique, est-il important pour les chercheurs ? La démarche de type ethnographique, qui se traduit par une présence longue et répétée auprès des personnes rencontrées, loin de l'interview-express, est nourrie par les réflexions menées par l'auteure depuis plusieurs années sur les bifurcations politiques et trajectoires d'engagement. Dans ses recherches précédentes, Ioulia Shukan a beaucoup utilisé la sociologie des crises politiques de Michel Dobry, s'est intéressée au métier de député en suivant des trajectoires d'élu.e.s, et plus récemment a analysé en détail les dispositifs 
et les routines de mobilisation sur le Maïdan en utilisant la notion de protagonisme $(\mathrm{H}$. Burstin) pour comprendre comment le « citoyen ordinaire » peut s'engager dans une action révolutionnaire qui va bouleverser à la fois ses représentations politiques et sa vie quotidienne ${ }^{16}$. C'est donc bien sûr aussi le regard de la chercheuse qui transparaît, avec la liberté pour cet exercice de se passer de la médiation de la langue ou de l'appareil académiques, pour restituer la matière très riche et incarnée de ses entretiens et de ses observations avec sensibilité et justesse.

16 Alexandra Goujon et Ioulia Shukan, « Sortir de l'anonymat en situation révolutionnaire. Maïdan et le citoyen ordinaire en Ukraine (hiver 20132014) », Politix, 4/2015, n 112, pp. 33-57. 